\title{
GRASS GIS for topographic and geophysical mapping of the Peru-Chile Trench
}

\author{
Polina LEMENKOVA ${ }^{1, *}$
}

${ }^{1}$ Schmidt Institute of Physics of the Earth, Russian Academy of Sciences. Laboratory of Regional Geophysics and Natural Disasters (Nr. 303), Department of Natural Disasters, Anthropogenic Hazards and Seismicity of the Earth. Bolshaya Gruzinskaya Str. 10, Bld. 1, Moscow, 123995, Russia. https://orcid.org/0000-0002-5759-1089

* Corresponding author: pauline.lemenkova@gmail.com

Received on 03-05-2020, reviewed on 25-08-2020, accepted on 15-09-2020

\begin{abstract}
The study area is located along the western continental margins of South America, Peru-Chile Trench south-east Pacific Ocean, geographically encompasses $90^{\circ}$ to $60^{\circ} \mathrm{W}$ longitude and $55^{\circ} \mathrm{S}$ to $0^{\circ}$ latitude. The study aims to perform a spatial analysis using GRASS GIS approach applied for processing and visualizing topographic and geophysical data on the study area. Data include following raster grids: topographic SRTM_15PLUS raster grid with 15 arc-second resolution, geoid model (EGM96), geophysical fields and gravity maps (marine free-air gravity and vertically corrected free-air gravity). The thematic grids were mapped by GRASS GIS modules and visualized for comparative analysis. Spatial analysis included plotting slope aspect, profile curvature, terrain elevation and modeled topographic classes based on the neighborhood analysis. The results include visualized geophysical and topographic maps of the study area showing correlation between the geophysical fields and topographic elevation. The variety of forms of the submarine relief of the Pacific Ocean seafloor was formed as a result of complex factors: tectonic movements, dislocations, active volcanism, geologic variations in rock density, which is reflected in visualized gravity and geoid maps. The actuality of the study is explained by high potential commercial interests in deep-water mineral resource deposits, oil and gas, which make ocean seafloor studies one of the most promising topics in geoscience. At the same time, the need for programming applications for big data analysis in geosciences requires testing advanced scripting approaches in cartography. Therefore, the current paper presents a multi-disciplinary approach combining geological analysis with technical cartographic aspects of data analysis and visualization.
\end{abstract}

Keywords: South America, GRASS GIS, cartography, gravity, geoid, topography

\section{Rezumat. Grass-GIS pentru cartarea topografică} și geofizică a Gropii Peru-Chile

Zona de studiu este localizată în marjele continentale vestice ale Americii de Sud, Groapa Peru-Chile în sud-estul Oceanului Pacific, cuprinde geografic $90^{\circ}-60^{\circ} \mathrm{V}$ longitudine și $55^{\circ} \mathrm{S}$ până la $0^{\circ}$ latitudine. Scopul studiului este realizarea unei analize spațiale folosind abordarea GRASS GIS aplicată pentru prelucrarea și vizualizarea datelor topografice și geofizice din zona de studiu. Datele includ următoarele griduri raster: raster SRTM_15PLUS topografic cu rezoluție de 15 secunde în arc, model geoid (EGM96), câmpuri geofizice și hărți gravitaționale (gravitație aer liberă marină și gravitație aer liberă corectată vertical). Rețelele tematice au fost reprezentate cu GRASS GIS și vizualizate pentru analiză comparativă. Analiza spațială a inclus aspectul de pantă, curbura profilului, altitudinea terenului și clase topografice modelate pe baza analizei de vecinătate. Rezultatele includ hărți geofizice și topografice ale zonei de studiu care prezintă corelația între câmpurile geofizice și creșterea topografică. Varietatea formelor reliefului submarin al oceanului Pacific a fost configurată ca urmare a unor factori complexi: mișcări tectonice, discolații, vulcanism activ, variații geologice ale densității rocilor, care se reflectă în hărțile vizualizate ale gravitației și geoidelor. Actualitatea studiului este explicată de interesele comerciale potențiale ridicate în depozitele de la adâncime, petrol și gaze, ceea ce face ca studiile de pe malul oceanului să fie unul dintre cele mai promițătoare în direcțiile de geoștiință. În același timp, nevoia de programare a aplicațiilor pentru analiza datelor în geoștiințe necesită testarea abordărilor avansate de script în cartografie. Prin urmare, lucrarea actuală prezintă o abordare multidisciplinară, combinând analiza geologică cu aspecte cartografice tehnice ale analizei și vizualizării datelor.

Cuvinte-cheie: America de Sud, GRASS GIS, cartografie, gravitatie, geoid, topografie

\section{Introduction}

The study of the bathymetry of the ocean seafloor and its structure is one of the most important means for understanding the principles of the geological structure and development of the oceanic crust. Modeling seafloor and development of the GIS based methods for its visualization facilitates ocean exploration and assists in prognosis of the vast mineral resources hidden in the ocean: petroleum and gas, raw materials, sand and gravel, phosphorite, corals, biogenic carbonates, heavy metal ores
(Seibold \& Berger, 1993). The ocean seafloor has continuously been an object of the geomorphological, geological and geophysical research (Suetova et al. 2005; Kuhn et al. 2006; Gauger et al. 2007; Schenke \& Lemenkova, 2008; Jamieson et al. 2010; ContrerasReyes \& Carrizo, 2011; Hu et al. 2016; Stewart \& Jamieson, 2018; Lemenkova, 2019a, 2019b; 2019c; 2020e; Jamieson \& Stewart, 2020).

The analysis of the correlation between the seafloor topography, deep geologic structure of the oceanic seafloor rocks and anomalies in geophysical fields reveals the role of various factors in its formation. Furthermore, it helps understanding the origin and evolution of the morphostructure of the 
ocean seafloor in the view of plates tectonics. The morphostructure of the ocean seafloor reflects the geological structure and tectonics of the oceanic crust in the submarine topography of the seafloor. The morphostructure of the submarine relief of deep-sea trenches mirrors the geologic development and tectonic movements, volcanism and the geological structure of the ocean floor in the specific area of plate subduction that causes formation of the oceanic trenches. However, the advanced mapping and visualization of such structure as oceanic seafloor is only possible by means of advanced technical mapping, remote sensing and GIS.

Gravimetric studies and visualization are of great importance and stand apart in the complex of geological and geophysical studies focused on the World Ocean, since gravimetric modeling enables to detect density variations at different depths of the Earth (Chambat \& Valette, 2005; Claessens, \& Hirt, 2013), detect isostatic areas (Gvirtzman et al. 2016). Detailed studies enable to detect crust strength, asthenosphere viscosity in the upper mantle, create thermochemical convection models based on the analysis of basalt content, showing the influence of viscosity of mantle on the evolution and distribution of Earth's mantle heterogeneity (Yan et al. 2020), detect impact factors that affect isostasy instability, to mention some. Moreover, the study of the gravitational field of the oceans is crucial for correct modelling of the Earth's shape, for navigation purposes, for calculation of the orbits of the artificial Earth satellites and trajectories of the space research vehicles.

Along with collecting gravimetric data on the World Ocean, a mapping of the free-air gravity anomalies has been continuously improved and updated with the beginning of the history of gravimetric measurements in early 20th century. Thus, the first gravity observations and regular mapping has been performed by Dutch scientist Vening-Meinesz in 1929 for the region of Indonesia where he measured horizontal and vertical accelerations, angular movements of the pendulum apparatus and created a formule for the correction for deviations of gravity and initiated gravity observations. The first map of the free-air gravity anomalies in Bouguer correction for the Pacific Ocean was created in the U.S. using both pendulum and marine gravity observations. Gravity measurements were then continuously performed using methods of the advanced data analysis (Drinkwater et al. 2003; Knudsen et al. 2011; Eshagh, 2013; Godah et al. 2018).

\section{Study Objectives}

This study contributes to the investigations of the oceanic seafloor with a case study of the South
America region and specifically, Peru-Chile trench bordering the continent on the west in the south-east Pacific Ocean. The objectives of this work included:

1. visualizing the relationships between the morphostructure forms of the submarine relief, the structure of the oceanic seafloor;

2. mapping anomalies in geophysical fields and gravity in south-east Pacific Ocean;

3. cartographic modelling of the variations in the and the geoid model in the study area;

4. literature based analysis of the geological structure in the Peru-Chile Trench, South America;

5. technical testing of GRASS GIS scripting functionality and use of its various modules;

6. spatial analysis of the topographic patterns: slope, aspect, elevations and curvature distribution and their relationship with the main topographic structure of the ocean seafloor in the region of the Chile-Peruvian Trench, the features of their geomorphic structure and dissection;

7. textual based analysis of the role of the tectonic movements, faults, volcanism, and sedimentation in the formation of the ocean floor based on the extensive literature review;

8. visualization of the bathymetry of the submarine relief and morphostructure of the seafloor in western part of South America.

\section{Study Area}

The study area is located in the western continental margins of South America in the PeruChile Trench, which stretches as a narrow strip along its coast, and geographically lies between $90^{\circ}$ to $60^{\circ} \mathrm{W}$ longitude and $55^{\circ} \mathrm{S}$ to $0^{\circ}$ latitude. (Fig. 1). The Peru-Chile Trench is formed along the continental margin slope of South America in the subduction zone of Nazca and Antarctic plates of the Pacific Ocean under the South American Plate. The forearc region of the South American Plate margin (northern Chile) is notable for subduction erosion and regional uplift (Adam \& Reuther, 2000). Since oceanic plates are more dense than continental plate, their structure is processed and modified as a result of physicochemical processes in the collision zone. As a result, a new continental crust is formed, which builds up the edges of the continental plates and Peru-Chile Trench.

The region of South America along the Pacific margin has a complex tectonic setting which should be briefly described. Detailed studies shown that geometry, geospatial trending in orientation, kinematics and time of deformation differ in the Atacama fault system, northern Chile (Ruthven et al. 2020). The continental margins were formed along the eastern periphery of the Pacific Ocean, with changing zones of the accumulation and subduction of the tectonic plates. This was caused by the partial 
overlapping of the axis of extension of the mid-ocean ridge by the continent. Besides, various exogenous factors affect the formation of the deep-sea trenches: sediment accumulation, erosion and deposition and movement of sediments, causing significant geomorphological changes in the relief on the continental slopes of the Pacific Ocean (Lemenkova, 2018a; 2018b). The Nazca and Antarctic plates move eastwards and subduct under the Peru-Chile trench. Located to the norther, Panama and adjacent minor tectonic plates move eastward and north-eastward and also experience subduction at the junction with the Middle America (Guatemala) Trench (Lemenkova, 2019f).

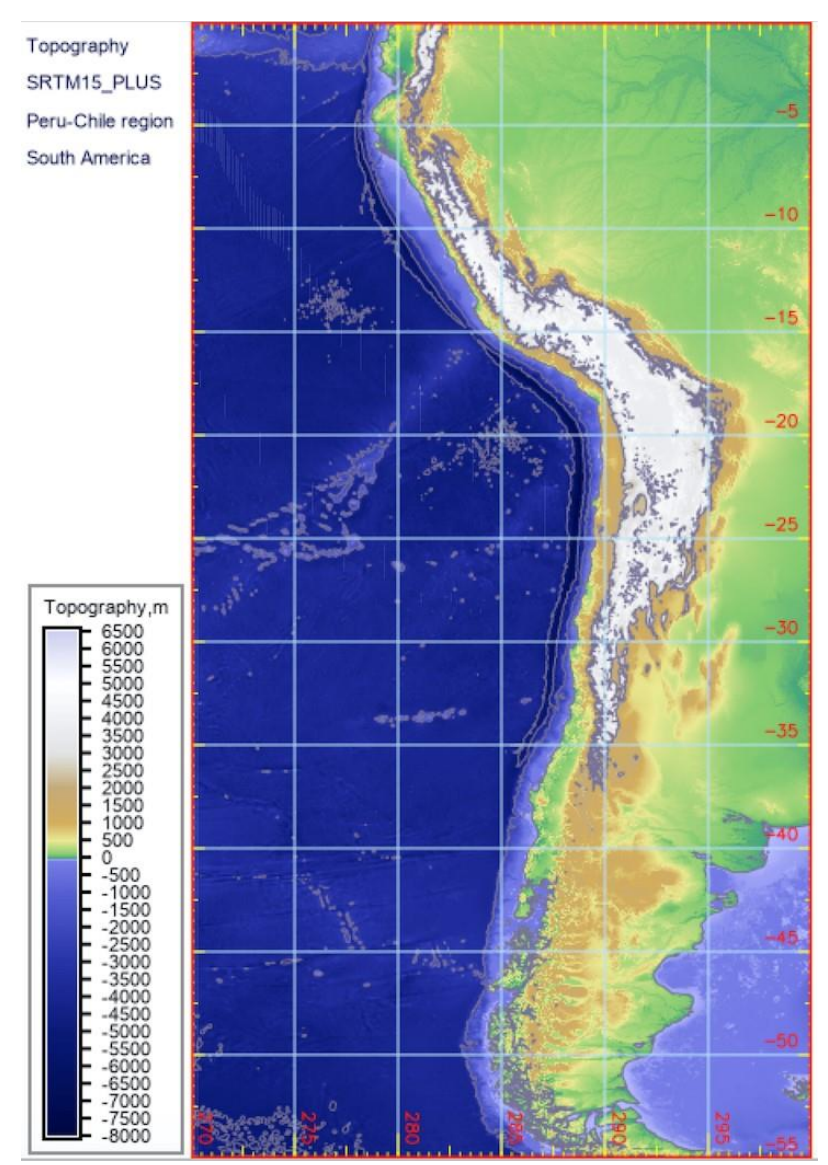

Fig. 1: Topographic map of the Peru-Chile Trench and western segment of South America, Pacific Ocean. Cartographic mapping: GRASS GIS. Raster grid: SRTM_15PLUS

The southern part of the Peru-Chile Trench is notable for transform fault off the coast of Chile which is formed in the boundary of the tectonic plates sliding past one another. Bending of the tectonic plates prior to subduction is caused by the negative buoyancy of the sinking plate, that is, a slab pull (Contreras-Reyes \& Osses, 2010).
The region of the Peru-Chile Trench is notable for high seismicity and repetitive earthquakes (Das et al. 2020). Thus, the seismic belt in the east of the Pacific Ocean extends along the active continental margins of South America, including Peru-Chile Trench and continuous sequence of mountain ranges of Andes and Cordillera. This makes the region of South America along the Peru-Chile Trench notable for a large number of catastrophic earthquakes with magnitudes of 7.0-8.5. Many shallow earthquakes are also located along the Peru-Chile Trench and neighboring coastal land areas. The fault plane here is vague and tilted at a slight angle (20-25 ) reaching depths of 200-250 km. Focal hypocenters are in depths at 250-500 km are almost not detected, but at a depth of $500-700 \mathrm{~km}$ there is another zone of earthquake foci on a steeper falling focal plane, which indicates a fracture of the oceanic plate moving under the continent.

The Nazca Plate plays important role in the formation of the Peru-Chile Trench (Yáñez et al. 2002). At its eastern border it adjoins the Pacific Plate along the East Pacific Rise and borders the Antarctic Plate along the Chile Rise. The eastern edge of the Chile Rise subducts beneath the South American plate at the Chile Triple Junction., which is formed in the place of collision of three tectonic plates (Antarctic, South America and Nazca) causing huge stress on sides of the fault, break of rocks and earthquakes along the South America slope (Espurt et al. 2008).

The eastern part of the Nazca Plate is sinking along the Peru-Chile Trench, which causes the formation of Andes. As a consequence, the Cordillera of the Andes as an orogenic belt was built up by thickening of South American plate crust (Faccenna et al. 2017). Such complex movements of three tectonic plates result in numerous earthquakes along the Peru-Chile Trench with the largest earthquake ever recorded (magnitude 9.5) in 1960 (Lara et al. 2004; Cisternas et al. 2017).

During the Oligocene and Miocene periods, the Chile rift zone was stretching along the modern South Galapagos and Chile uplifts to the north, merging with the rift zone of the East Pacific Rise, until the California Gulf rift through a transform fault. After the Mesozoic period, the southern segment of the Pacific Ocean seafloor around the South America, rift zone and South Pacific Rise did not undergo significant tectonic rearrangements and continued to actively developing up to the present time. This caused gradual separation of the Pacific and Antarctic tectonic plates which affected actual geomorphic structure of the seafloor. Further extensive studies on South America tectonics and the geology of the PeruChile Trench region can be found in relevant publications (Bourgois et al. 2000; Alvarado et al., 2007; Cobbold et al. 2007; Scherwath et al. 2009; Geersen et al., 2011). 


\section{Methods}

There is a vast variety of spatially distributed geophysical and geological datasets, both in raster and vector formats. The problem of its interpretation, analysis and visualization is important and requires an integrated systematic approach with correctly chosen GIS software.

For instance, statistical modeling of spatial phenomena and geological variables enables to sort, plot and analyze measurements as a datasets and obtain a model of the data distribution in space (Pyrcz \& Deutsch, 2014; Klaučo et al. 2013a; 2013b; Webster \& Oliver, 2007; Lemenkova, 2019e, 2020f; Kurowicka \& Cooke, 2006; Reynard et al. 2010). Statistical data analysis often includes various types of geological modeling applied for tabular datasets aimed at data inventory, following the conceptual geological modeling, mathematical simulations, plotting and approximations for the assessment of physical properties of rock and soil types (Lindh, 2003; Lindh \& Winter, 2003).

In contrast with the statistical approach, cartographic data analysis requires strong mapping techniques, since data analysis by GIS reveals hidden information and correlation through visualization which is the key concept in cartography. There are many and various GIS software that can be used for data processing and cartographic visualization, and the choice of GIS is often a challenge. This is the case of ArcGIS, a commercial desktop GIS developed by ESRI, often used in geospatial research due to its functionality and structural architecture as a modular system (ArcMap, ArcCatalog, ArcToolbox, ArcScene, ArcGlobe) and a variety of functions for data processing (Klaučo et al., 2014; 2017). One of the advantages of ArcGIS is its compatibility with Python which is powerful for geographic data analysis and interpretation (Lemenkova, 2019h; 2019i).

The Generic Mapping Tools (GMT) is another cartographic program which, in contrast to GIS, is a scripting toolset run from the console. GMT is a powerful mapping instrument often used for geophysical data analysis, effective visualization and interpretation (Lemenkova, 2019d; 2020a; 2020b, 2020c, 2020f). Other examples of geodata analysis include application of remote sensing data analysis in environmental, spatial, marine biological or oceanographocal studies (Jamieson, 2018; Stewart \& Jamieson, 2019; Lemenkova, 2019g; Abdel-Mageed et al. 2020; Jamieson et al. 2020).

The GRASS GIS (Geographic Resources Analysis Support System) was selected for this research as an excellent multi-functional free GIS (Neteler \& Mitasova, 2004). GRASS GIS is an open source free software with many applications (Neteler, 2001; 2005; Mitasova et al., 2005). The main reason for the GRASS GIS consists in its combination of scripting console-based approach with powerful functionality in geomorphometric analysis: topographic analysis of tangential and profile curvature, slope, aspect and visualization of raster and vector datasets via the command line.

\section{Geoid modelling}

The geoid dataset was visualized using Earth Gravitational Model (Pavlis et al., 2012; Lemoine et al., 1998), geopotential models of the Earth EGM96, a version from 1996, as the geoid reference of the World Geodetic System. Worldwide, the geoid undulations range from $-107 \mathrm{~m}$ to $85 \mathrm{~m}$ relative to the WGS 84 ellipsoid. In geodesy, the free-air reduction condensed the topographic shape, so the station is projected onto the geoid, while geoid is a surface of the terrestrial masses, and gravity is measured on the geoid. Current advances in physical geodesy present technologies of optical frequency references using lazer spectroscopy utilized in global satellite navigation systems and satellite geodesy (Giorgi et al. 2019). The derivation of the geoid from gravity after estimating gravity measurements is based on the assumption of the geoid as hypothetical spherically symmetric, rotating Earth, as described in geodetic studies (Vaniček et al. 2001; Steinberger et al. 2010).

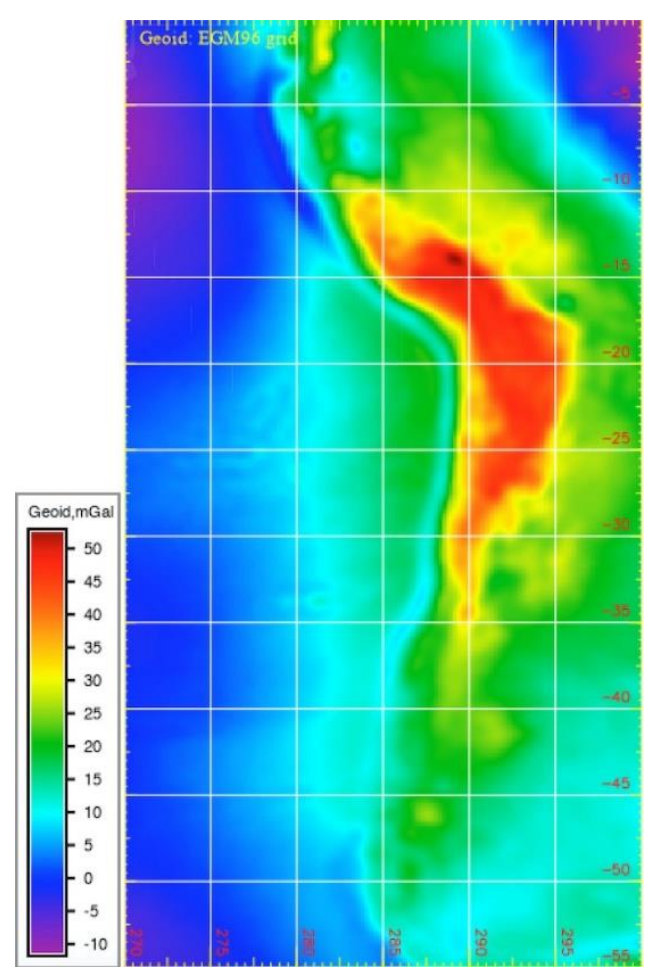
Fig. 2: Geoid model of the Peru-Chile Trench and western segment of South America, Pacific Ocean. Raster grid: EGM96 (geoid.egm96.grd). Cartographic mapping: GRASS GIS 
The geoid was visualized using modules of GRASS GIS and GDAL library for raster import:

\section{\#!/bin/sh}

1. r.in.gdal -o pct_geoid.nc out=pct_geoid

2. g.list rast

3. d.mon $w \times 0$

4. d.erase

5. g.region res $=0.001$

6. g.region raster=pct_geoid $-\mathrm{p} \quad-\mathrm{w} \quad-\mathrm{m}$ nsres $=0.0001$ ewres $=0.0001$ res $=0.0001$

7. r.colors pct_geoid col=roygbiv

8. d.rast pct_geoid

9. d.redraw

10. d.grid border_color=yellow text_color=red

11. r.info pct_geoid

12. d.legend raster $=$ pct_geoid range $=-12,53$ title $=$ Geoid, $\mathrm{mGal}$ title_fontsize $=8$ font $=$ Helvetica fontsize $=8 \quad$-t $\quad-b \quad$ bgcolor $=$ white label_step $=5$ border_color $=$ gray thin $=8$

13. d.text text="Geoid: EGM96 grid" color=yellow size $=1.0$ font $=$ "Times New Roman" linespacing $=0.7$

\section{Topographic mapping}

The topographic DEM data is based on the SRTM15_PLUS raster grids of the seafloor global fabric (Becker et al., 2009; Olson et al., 2016). The SRTM15_PLUS presents a grid at 15 arc-second resolution (ca. $500 \mathrm{~m}$ ). Terrain elevations of the SRTM15_PLUS are based on the data from the SRTM and ASTER DEMs while ocean bathymetry is based on bathymetric predictions from the global gravity model from CryoSat- 2 and Jason- 1 with depth soundings at 15 arc-second resolution. The mapping was done using a sequence of 19 GRASS GIS modules in a shell script:

\#!/bin/sh

1. g.list rast

2. r.info pct_relief

3. d.mon $w \times 0$

4. g.region raster=pct_relief $-p$

5. v.in.region output $=$ pct_bbox

6. g.list vect

7. v.info map=pct_bbox

8. r.colors pct_relief col=sitm_plus

9. d.rast pct_relief

10. r. contour pct_relief out $=$ TopoPCT step $=2500$

11. d.vect TopoPCT color $=$ '100:93:134' width $=0$

12. d.grid size $=5$ color $=$ '172:219:250'

border_color $=$ yellow width $=0.1 \quad$ fontsize $=8$

text_color=red

13. d.vect pct_bbox color $=$ red width $=3$ fill_color="none"

14. r.info pct_relief
15. d.legend raster $=p c t$ relief range $=-$

8100,6600 title=Topography, $m$ title_fontsize $=8$ font $=$ Arial fontsize $=8 \quad-t \quad-b \quad b g c o l o r=w h i t e$ label_step $=500$ border_color $=$ gray thin $=8$

16. d.text text="Topography" color='0:0:51' size $=1.5$ font $=$ Arial

17. d.text text="SRTM15_PLUS" color='0:0:51' size $=1.5$ font $=$ Arial

18. d.text text="Peru-Chile region" color $=$ '0:0:51' size $=1.5$ font $=$ Arial

19. d.text text="South America" color $=10: 0: 51 '$ size $=1.5$ font $=$ Arial

Spatial analysis is particularly problematic in submarine geomorphology, where the bathymetry as inferred from the remote-sensing data such as Digital Elevation Models (DEMs) and computer-based modelling is the only observable data. Therefore, high-resolution DEM of Earth SRTM 15_PLUS was used to map terrain elevation and topographic derivatives evaluating slope features.

\section{Free-air gravity mapping}

Free-air gravity data were taken from the satellite altimetry-derived gravity grid of Sandwell and Smith (2009). The geoid undulations, marine free-air gravity and vertical gravity anomalies, as well as gravity gradient changes reflect the density variations of the Earth which is caused by different density in geochemical content of rocks. The difference between the geophysical and geodetic concepts of gravity mirrors the difference between the ellipsoid and the geoid. The gravity anomaly is explained by the gravitational effect of the seafloor topography and crust-mantle rock density contrast, reflected in geopotential models of the Earth, e. g. EGM-2008 (Hirt et al. 2016). The compiled free-air and vertical gravity anomaly maps were plotted around the PeruChile Trench region to visualize the variation in the processes in the oceanic seafloor surrounding the South America region.

Gravitational anomalies have sharp gradients along the active continental margins of the eastern Pacific Ocean, which is caused by the contrasting geomorphology: coastal mountainous land areas on the one hand and deep-sea trenches along the foot of the continental slope on the other. Besides, the gravitational values are affected by the variations in density of the oceanic lithosphere, isostatically compensated by ocean deepening, which is reflected in the ocean-floor structure (Tenzer et al. 2015). Faye anomalies vary from the strongly positives over Andes to strongly negative values $(100-200 \mathrm{mGal})$ over the deep-sea Peru-Chile Trench. Other studies present gravity models that reveal crustal thickening of the Andes Cordillera and show that dip and depth of the oceanic subduction varies in its different segments (Tamay et al. 2018). The Bouguer anomalies, 
representing the variations in the gravity corrected for height at the Earth's surface (Meurers, 2017) increase sharply from the strongly negative above the coastal mountain up to +300 mGal above the adjacent ocean seafloor. The free-air gravity anomalies (Fig. 3) show gravity with height correction.

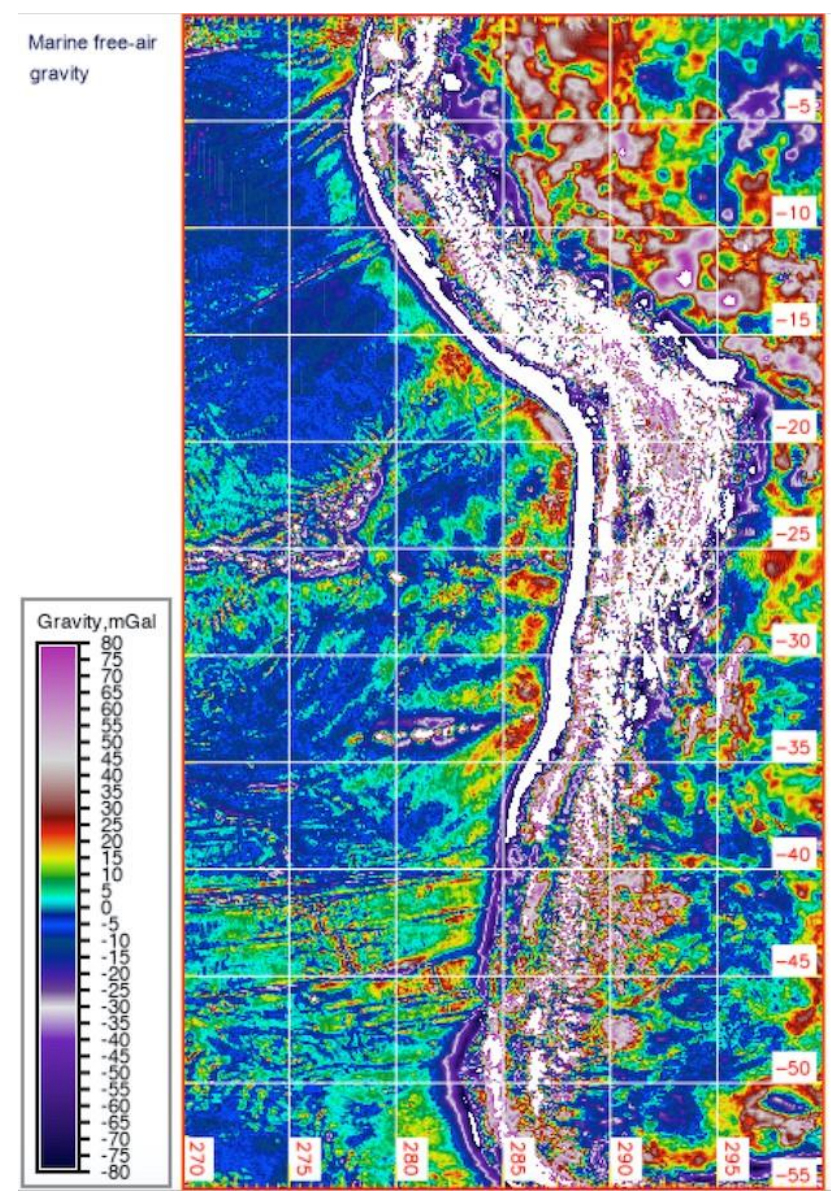

Fig. 3: Marine free-air gravity model of the Peru-Chile Trench and western segment of South America, Pacific Ocean. Raster grid: grav_27.1.img (Scripps Institution of Oceanography). Cartographic mapping: GRASS GIS

\section{DEM spatial analysis}

The spatial analysis based on the Digital Elevation Models (DEM) is performed using various raster datasets visualizing topography of the study area and its derivatives. Using ' r.slope.aspect' GRASS module, four topographic derivatives were modeled: slope, aspect, tangential and profile curvatures of the slope. Hence, the topographic analysis has been performed using GRASS GIS module using scripting sequence of commands as follows:

\#!/bin/sh

1. r.slope.aspect slope $=$ PCTslope pcurvature $=$ PCTpcurv tcurvature $=$ PCTtcurv .

2. d.mon $w \times 0$
3. r.colors $\mathrm{map}=\mathrm{PCT}$ aspect color $=$ aspectcolr

4. d.rast PCTaspect

5. d.grid size $=5$ color $=$ '252:242:180' border_color=blue width $=0.1 \quad$ fontsize $=8$ text_color=blue

6. d. legend raster $=P C T a s p e c t$ title $=$ Aspect, $\mathrm{grad}$ title_fontsize $=8$ font $=$ Arial fontsize $=8 \quad-t \quad-b$ bgcolor $=$ white label_step $=30$ border_color $=$ gray thin $=8$

7. d.text text="Aspect map" color=blue size $=1.0$ font $=$ "Arial" linespacing $=0.7$

The given above example is a script visualizing the aspect map (Fig. 5). Other topographic maps of the Peru-Chile Trench (PCT) have been plotted using this script as a template with inserted target layouts (PCTslope, PCTtcurv, PCTtcurv), respectively.

Spatial analysis using neighborhood analysis approach and cross-category statistics was performed using 'r.neighbors' GRASS GIS module by shell script in 20 steps:

\#!/bin/sh

1. d.mon $w \times 0$

2. g.region raster $=$ pct_relief $-p$

3. r.colors pct_relief $\mathrm{col}=$ elevation

4. r.info pct_relief

5. d.rast pct_relief

6. d.mon $w \times 1$

7. r.neighbors pct_relief out $=$ pct_relief_smooth7 method $=$ diversity size $=7$

8. r.colors pct_relief_smooth7 col=elevation

9. d.rast pct_relief_smooth7

10. r.info pct_relief_smooth7

11. d.vect pct_bbox color $=$ red width $=3$ fill_color="none"

12. r.contour pct_relief out $=$ TopoPCT step $=2500$ --overwrite

13. d.vect TopoPCT color $=$ '100:93:134' width $=0$

14. d.grid size $=5 \quad$ color $=$ grey border_color=yellow width $=0.1 \quad$ fontsize $=8$ text color=red

15. d.legend raster $=$ pct_relief_smooth7 range $=1,49$ title $=$ SmoothTopo title_fontsize $=8$ font $=$ Arial fontsize $=8$ bgcolor $=$ white label_step $=10$ border_color $=$ gray thin $=8$ units $=\mathrm{m}-\mathrm{v}-\mathrm{t}-\mathrm{b}$

16. d.text text="Topography" color='0:0:51' size $=1.5$ font $=$ Arial

17. d.text text="SRTM15_PLUS" color='0:0:51' size $=1.5$ font $=$ Arial

18. d.text text="Spatial analysis" color='0:0:51' size $=1.5$ font $=$ Arial

19. d.text text="Neighborhood" color='0:0:51' size $=1.5$ font $=$ Arial

20. d.text text="Method diversity" color=' $0: 0: 51^{\prime}$ size $=1.5$ font $=$ Arial

The presented map (Fig. 8) shows the topographic surface recalculated by method of neighborhood diversity. This approach is based on the GRASS GIS 'neighborhood' operator (Neteler \& Mitasova, 2008) 
which re-calculates a new value for each cell as a function of the values in its neighboring cells. Hence, the cells in a raster grid become new center cells of a neighborhood. The algorithm of the neighborhood approach consists in the window which moves throughout the map capturing and recalculating cells. In this research, the 'diversity' approach was applied. It computes the number of cell values within the neighborhood with the defined size of 7 .

\section{Results}

The Peru-Chile Trench is the most extended continuous submarine morphostructure in the World ocean (total length is $\mathrm{m}$ ). The geomorphology of its southern segment is characterized by valley-block dissection with a minor trench where depths $<4500$ $\mathrm{m}$. Northern segment of the Peru-Chile Trench is presented by the continental slope with simpler structure, a convex cross-section profile with steepness gradually increasing downward. The seafloor shape is narrow and mostly flat. The bathymetry varies for both trenches with maximum depths of $8069 \mathrm{~m}$ in its Chilean segment and $6601 \mathrm{~m}$ in the Peruvian segment.

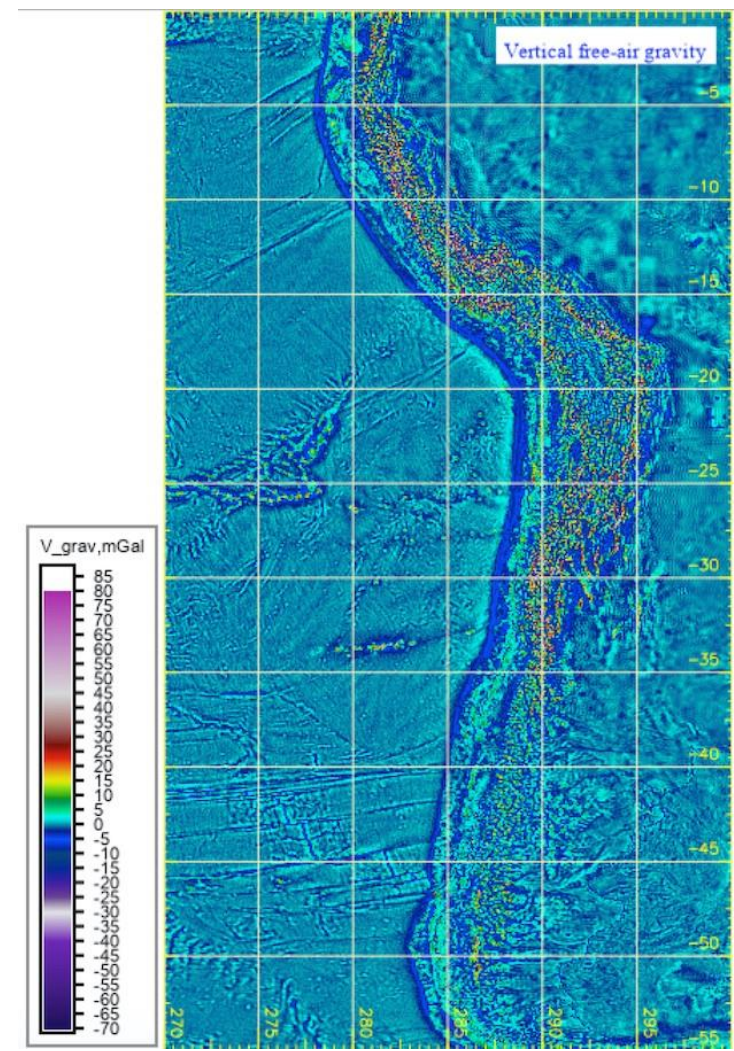

Fig. 4: Vertical free-air gravity model of the Peru-Chile Trench and western segment of South America, Pacific Ocean. Raster grid: curv_27.1.img (Scripps Institution of Oceanography). Cartographic mapping: GRASS GIS
The seafloor geodynamics of the Pacific Ocean is determined by the lateral movements of several large tectonic plates: Pacific, North American, Antarctic, Peruvian-Chilean, and microplates: Panama, Guatemala, and Tehuantepek. The speed of the expansion (opening) of the rift and, accordingly, tectonic plate movement in the South and East Pacific rises, is 2.0-4.0 and 4.2-6.0 cm/year, respectively. Current fault activity in the coastline of northern Chile is presented by two large features (Coastal Scarp and the Atacama Fault) having active deformation since Quaternary.

The zones of junction of the oceanic and continental lithosphere on the tectonic plate gradually become tectonically passive regions and the main leading process affecting the topography of the trench becomes the immersion of the marginal parts of the continents and formation of a sedimentary rock cover. This briefly describes the formation of the PeruChile Trench morphostructure, the shelf, submarine fans and sediment deposits at the foot of the continental slope of South America.

Among other basins of the Pacific Ocean, the Peru and Chilean basins, together with Caroline, Melanesian, are characterized by slightly positive values of the Faye gravity anomaly (Fig. 3), while Northwest, Northeast, East Mariana Basin and Central Pacific Basin have slightly negative Faye gravity anomalies.

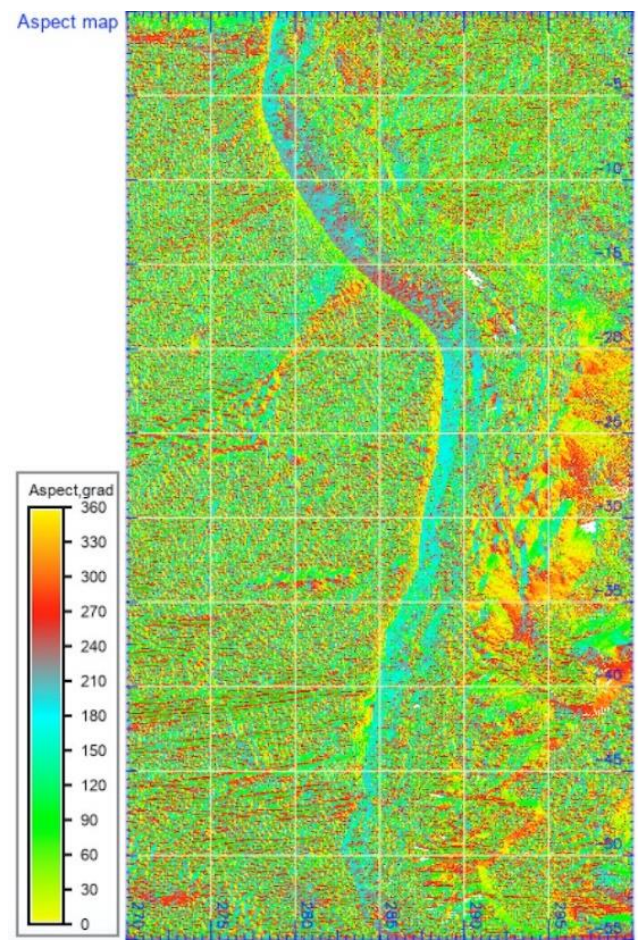

Fig. 5: Topographic aspect map: Peru-Chile Trench and western segment of South America, Pacific Ocean. Model based on processing raster SRTM_15PLUS grid. Cartography: GRASS GIS 
The free-air gravity anomalies reflect topographic structure of the region (compare Fig. 1 and Fig. 2). Gravity field of the Peru-Chile Trench (Fig. 3) is depicted as narrow strip (purple colored). The freeair gravity reach slightly positive values $(2-7 \mathrm{mGal}$, cyan color) above the topographic elevations, negative values ( 0 to $-10 \mathrm{mGal}$, dark blue color) on the most area of basins; 20-25 mGal (red color) can be seen on the Andes ares and above the ridges (Copiapo Ridge, Taltal Ridge and Iquique Ridge, Nazca Ridge in the coastal shelf zone). The values above $55 \mathrm{mGal}$ are notable in the high mountains of Andes with selected anomalies (dark purple color, below $-45 \mathrm{mGal}$ ) in the depressions. Thus, the distribution of the gravity field mirrors geological properties of rocks and their distribution over the study area, since density in the rocks affect gravity values.

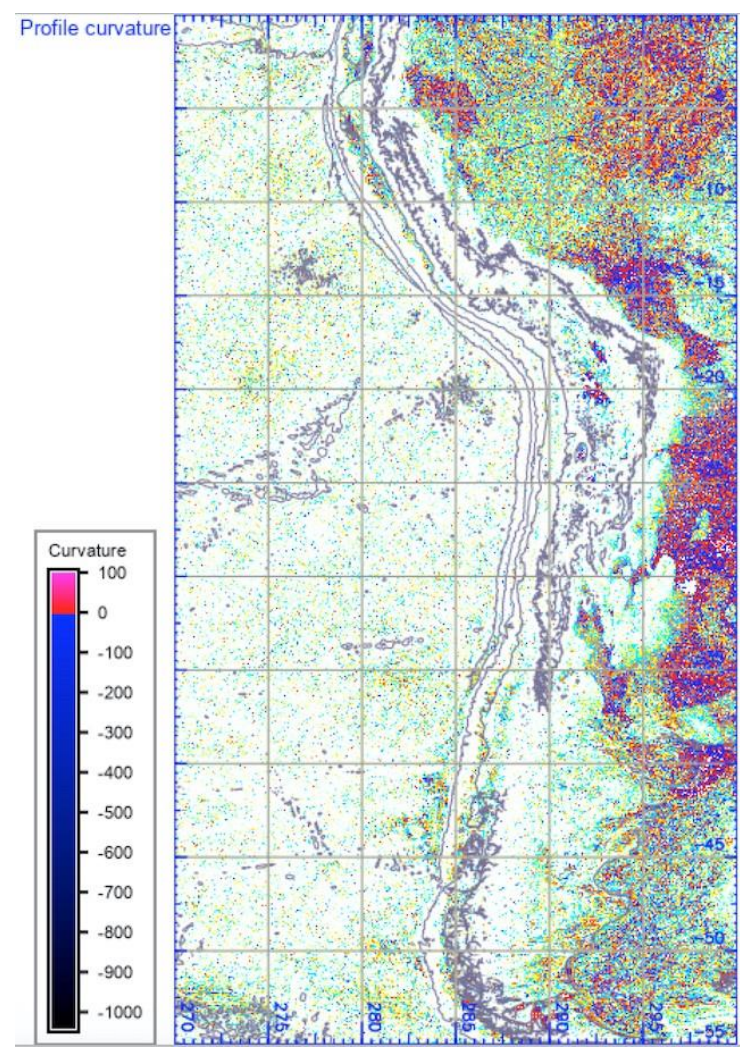

Fig. 6: Topographic profile curvature map: Peru-Chile Trench and western segment of South America, Pacific Ocean. Model based on raster SRTM_15PLUS grid. Cartography: GRASS GIS

Vertical free-air gravity raster shows vertical gradient of actual gravity (Fig. 4) which, compared with elevation map (Fig. 7) presents correlation between the gravity anomaly and topographic patterns. From the Poincare-Pray gradient Vanicek et al. (2001) define that larger local density results in smaller vertical gradient in absolute values, and proves existing approximately linear relation between the density and the vertical gradient of the gravity. Thus, the difference between mean vertical gradient of gravity on the Earth surface and the geoid shape can be obtained from mathematical computations and is visualized on Fig. 3 and 4.

The aspect map (Fig. 5) shows visualized geomorphic slope orientation, direction of gradient, steepest slope and flow direction in degrees. As can be seen (Fig. 5), the majority of degrees in orientation is presented by $45^{\circ}-100^{\circ}$ (bright green color) dominating the scene, followed by $250^{\circ}-290^{\circ}$ (red color) which follows the faults lines on the seafloor and $330^{\circ}-360^{\circ}$ (yellow), mostly for the terrestrial areas in the Andes. The Andes slope close to the Chile Trench (southern segment of the study area) has predominantly $160^{\circ}-200^{\circ}$ oriented slopes (cyan color).

The quantitative land-surface analysis such as topographic aspect of slope curvature enables to describe the topography of the surface and geomorphological processes at various spatial and temporal scales. Practical values of aspect maps in special-temporal analysis for instance, visualize changes in the geomorphic types using slope curvature or aspect categories which can be translated into geomorphological landforms which has been a study object for many papers continuously during recent decades (Stevenson et al., 2010; Sofia et al., 2013).

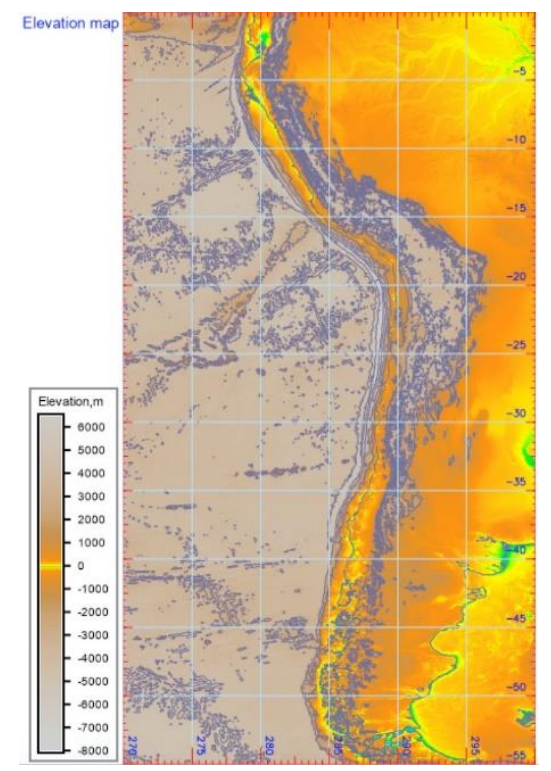

Fig. 7: Terrain elevation map based on raster SRTM_15PLUS grid: South America. Cartographic mapping: GRASS GIS

The topographic analysis was computed as a set of parameters (slope aspect and curvature) that indicates geometrical properties of the Earth's surface. These parameters describe surface 
mathematics at a cell point and in its immediate surroundings (neighbor cells) which is computed by GRASS GIS embedded functions using differential geometry by partial derivatives of the function mathematically approximating the surface.

The inclined plains of the accumulative sediment plumes formed along the foot of the continental slope, overlapping continental or marginal troughs. However, in the zones of active sediment absorption, the rate of sedimentation was insufficient to compensate for the deflections. As a result, the deepsea Peru-Chile Trench continued to develop in such areas as the most typical example of the zone stretching along the coast of South America.

The geomorphology of the western slope of South America is presented by the marine terrace resulted from a complex processes of tectonic erosion, which is also pointed by Clift et al. (2003). The marine terrace continuing as a continental slope into the western slope of the Andes mountain range. The surface of the shelf in the coastal zone is hilly, in the outer part of the shelf - more leveled. The depths of the outer shelf edge are mostly $50-80 \mathrm{~m}$, reaching on the submerged steps up to $150-200 \mathrm{~m}$.

Among the important features in the geological structure of the Peru-Chile Trench there are the following ones: 1) the placement of undeformed flatlying sediments against the $45^{\circ}$ steep eastern wall of the trench which is a unique process, since such sediments are usually swallowed up in the subduction zone; and 2) the grabben geomorphic structure of the trench.

The continental slope of the Peru-Chile Trench is formed by a stepped ledge with slope steepness and curvature varying along the coast of South America (Lemenkova, 2019). The curvature map indicates concave and convex areas related to the convergence and divergence curvatures of the geomorphic slopes. Negative and positive values on the grid indicate geomorphic variations: negative values show a concave surface on a grid while positive values indicate convex, respectively.

Therefore, the curvature map (Fig. 6) shows that the most dissected convex-shaped slopes (positive curvature values) are located in the terrestrial regions of the Andes (pink to purple colored areas) indicating that surface in the mountainous areas is upwardly convex at the computed cells. On the contrary, negative curvature values (bluish colored) demonstrate concave, that is, the surface is directed concave at that cell. Following this logic, values close to zero indicate flat or almost-flat surface (greenish colors on the map, Fig. 6).

The elevation map (Fig. 7) shows a visualized DEM based on the SRTM15_PLUS raster grid with a spatial analysis based on the neighborhood approach (Fig. 8). Along the continental margin of northern Peru exist mass rock wasting caused by the avalanche morphology, which covers the lower slope and trench axis seaward. Slope failures and landslides are a source of destructive events and cause both geographic and economic losses, which is also discussed in the published works on landslide geomorphology (Mergili et al. 2018; Lemenkova et al. 2012).

The variety of forms of the submarine relief of the Pacific Ocean seafloor was formed by the end of the Pliocene as a result of complex factors: horizontal and vertical tectonic movements, dislocations, active volcanism as well as various exogenous factors, e.g. sedimentation as the most important ones. During the Pleistocene, there were no significant rearrangements in the morphostructure of the Pacific seafloor with the exception of the formation of the new oceanic crust in the rift zones, volcanic island arcs and continental margins.

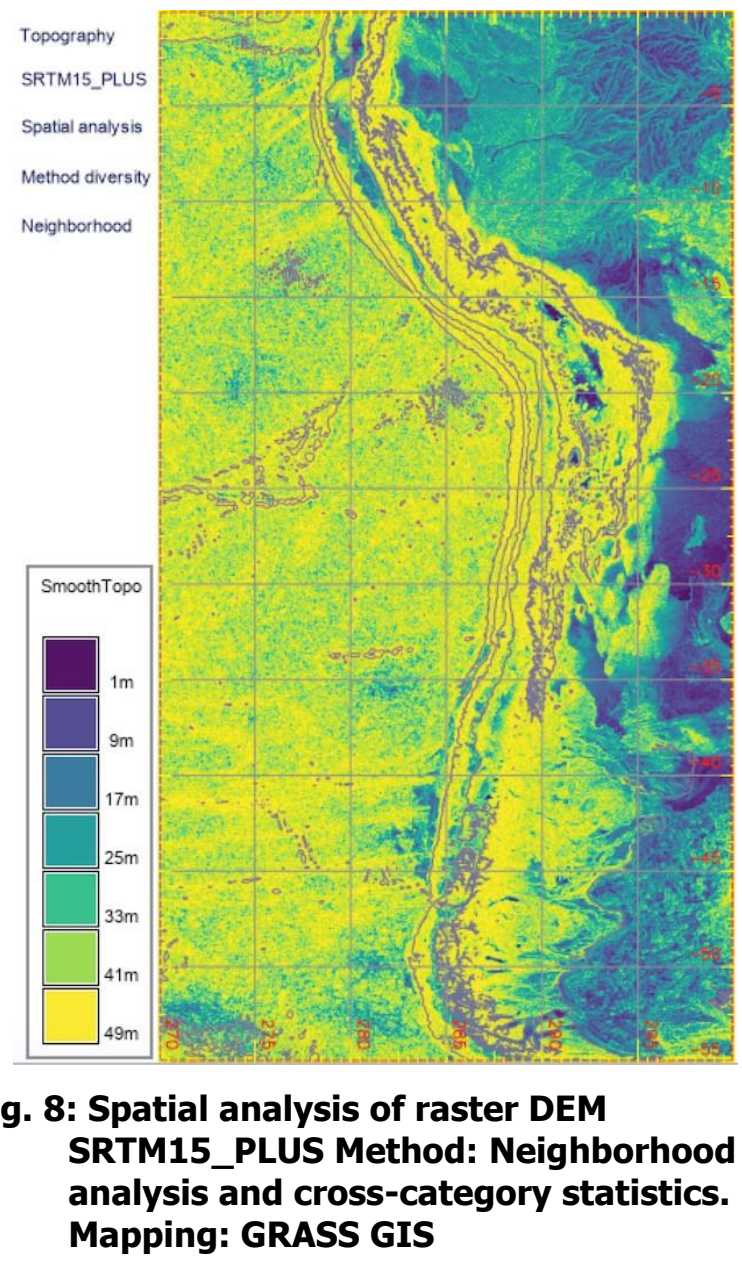

One of the most interesting geological phenomena of the Peru-Chile Trench consists in the formation of the Chile Triple Junction along the western coast of Chile. The Chile Triple Junction is formed in the place where three tectonic plates (Nazca, Antarctic and South America) intersect in a unique unprecedented way: an actively spreading mid-ocean ridge is being 
subducted beneath a continental South America Plate, which is further discussed by Lim et al. (2018).

The Bouguer gravity anomaly is corrected for the height at which it is measured and the attraction of terrain. Specifically, for the Pacific Ocean, the average level of the Bouguer anomalies varies in the basins of the Pacific Ocean. Thus, the Northeast Basin is notable by the lower positive Bouguer anomalies ( 250 to $350 \mathrm{mGal}$ ), increasing in its western part to 400 $\mathrm{mGal}$. The relatively low values of Bouguer anomalies (280-300 mGal) are noted in the Guatemala, Peru and Chile basins.

Such variations in gravity indicate differences in the subsurface rock density. Thus, higher gravity values are notable over the denser rocks, and vice versa, lower gravity values over the less dense rocks of the seafloor. In the Peru Basin along the South Galapagos Rise, slightly elevated anomalies from 5 to 18 are observed, mostly oriented in the submeridional direction, at some angle to the system of the anomalies of the East Pacific Rise.

Deep correlation between the geophysical settings and height elevation as effects of topography and geoid on gravity anomalies are reported recently by Pivetta \& Braitenberg, (2020). Furthermore, García et al. (2018) report example for the mountainous areas of Central Andes with rugged topography of the relief and show correlation between the geoid undulations, orogenic deformation and lower crust high-gravity anomaly, as well as the elastic thickness and heat flow, proving interplay between the geophysical and topographic settings.

\section{Discussions}

Practical values of the performed geomorphometric analysis consists in the need of comprehensive, geomorphic models describing continental and seafloor tectonics, bedrock geological evolution, slope curvature and erosion mathematically. This can be performed by the geomorphometric surface based analysis combining data on surface topography, geophysics, gravity fields analysis, coastal bathymetry, surface roughness and slope curvature, geologic dynamics and elevation mapping. The particular problem of the ocean studies is that in contrast to the terrestrial geoscience, there are fewer and more costly instrumented observations as well as restrained access to the study object (Mitchell, 2012). This necessarily makes a need for advanced methods of data analysis, GIS and remote sensing as key tool for correct spatial analysis.

As a recommendation for future studies, thematic datasets could be included in the research for more comprehensive analysis: e.g. marine biological data, sediments (transport, direction and volumes), earthquakes and volcanic activities affecting the shape of the seafloor. Testing various GRASS GIS modules for geophysical and tectonic mapping through overlay of data layers and accurate modelling is useful for study of the sediment transport and deposition, erosion and marine habitat modelling along the South American coasts. The bathymetric and geophysical data are useful for verification of modelling.

The actuality of the study is explained by high interests in deep-water mineral resource deposits, which make ocean seafloor studies one of the most promising in geoscience for investigations of the seafloor geophysics. Rapid development of the programming applications in geosciences creates a need for testing advanced scripting based GIS. Therefore, the paper contributed to the studies of topographic and geophysical analysis through technical approach of the open source GRASS GIS for advanced spatial analysis. This work presents a combination of various thematic data (tectonics, gravity, geoid, topography) to better understand the principles of the morphostructure and development of the ocean seafloor topography.

\section{Conclusion}

The methodological basis of the work is based on the morphostructure analysis of the seafloor relief in the Peru-Chile Trench, along the South America. The methodology includes GRASS GIS based spatial analysis, literature review, mapping and interpretation of the multi-source data, sequential geomorphological analysis developed to automatically obtain data on the slope steepness, aspect, elevation, geophysical anomalies, slope curvature, model of the smoothed topography using neighborhood diversity.

The comparative analysis of the geomorphological, geophysical, and geological datasets aimed to identify the correlation between settings of the submarine topography (elevations, slope, aspect, geophysical fields, curvature) with geologic processes and deep geomorphic structures.

Future research can include other areas of the Pacific deep-sea trenches using the proposed methodology of the GRASS GIS and application of the presented scripts. Nowadays, geophysical and geomorphological mapping is significantly improved with rapidly developed technical tools and instruments for measurements and GIS mapping. The mathematical improvements and corrections of gravity results in reduced influence of the random errors in the observation datasets, decreased the impact of surface relief and local variations in density of the Earth's crust. For instance, the Bouguer corrections errors caused by the seafloor roughness do not exceed $10-15$ mGal. 
The difficulties encountered in this research included two major points: 1) technical processes of data analysis: shell scripting, syntax of GRASS GIS; 2) data capture from the open sources (raster grids). A theoretical basis of the present work is the concept of the plate tectonics which explains factors in the relief formation. The extended functionality of GRASS GIS enables to arrange multi-source data in a project, process datasets, visualize correlations in maps through cartographic overlays.

The importance of this research consists in the actuality of geophysical, geomorphological and topographic studies for our understanding of the ocean seafloor. As a result of numerous international expeditions, there is now a big datasets available for mapping and modelling various parameters of the World Ocean with particular focus on the ocean seafloor geomorphology, tectonics, magnetic and gravity anomalies, heat flow. Processing of such massive data for modelling of the oceanic seafloor, prognosis of mineral resources and thematic mapping requires the use of the advanced tools for big data analysis. This paper was a contribution towards testings of such methods using functionality of GRASS GIS for scripting cartography.

\section{Acknowledgements}

I thank two anonymous reviewers whose comments and suggestions helped improve and clarify this manuscript. This research was implemented in the framework of the Project No. 0144-2019-0011, Schmidt Institute of Physics of the Earth, Russian Academy of Sciences.

\section{Author contribution}

The author of this paper (P. Lemenkova) performed all research steps: formulation of the problem and study goal, data collection (SRTM15_PLUS, EGM96), importing and converting via GDAL library, GRASS GIS shell scripting, cartographic mapping, literature review, geologic analysis, preparing, structuring and writing the manuscript.

\section{References}

Abdel-Mageed, W. M., Lehri, B., Jarmusch, S. A., Miranda, K., Al-Wahaibi, L. H., Stewart, H. A., Jamieson, A. J., Jasparsd, M., Karlyshev, A. V. (2020). Whole genome sequencing of four bacterial strains from South Shetland Trench revealing biosynthetic and environmental adaptation gene clusters. Marine Genomics, 54, 100782. https://doi.org/10.1016/j.margen.2020.100782
Adam, J., \& Reuther, C.-D. (2000). Crustal dynamics and active fault mechanics during subduction erosion. Application of frictional wedge analysis on to the North Chilean Forearc. Tectonophysics, 321, 297-325. https://doi.org/10.1016/S00401951(00)00074-3

Alvarado, P., Beck, S., \& Zandt, G. (2007). Crustal structure of the south-central Andes Cordillera and backarc region from regional waveform modeling. Geophysical Journal International, 170 (2), 858875. https://doi.org/10.1111/j.1365246X.2007.03452.x

Becker, J.J., Sandwell, D.T., Smith, W.H.F., Braud, J., Binder, B., Depner, J., Fabre, D., Factor, J., Ingalls, S., Kim, S.H., Ladner, R., Marks, K., Nelson, S., Pharaoh, A., Trimmer, R., Von Rosenberg J., Wallace, G., Weatherall, P. (2009). Global bathymetry and elevation data at 30 arc seconds resolution: SRTM30_PLUS. Marine Geodesy, 32, 355-371. https://doi.org/10.1080/01490410903297766

Bourgois, J., Guivel, C., Lagabrielle, Y., Calmus, T., Boulègue, J., \& Daux, V. (2000). Glacial-interglacial trench supply variation, spreading-ridge subduction, and feedback controls on the Andean margin development at the Chile triple junction area $\left(45-48^{\circ} \mathrm{S}\right)$. Journal of Geophysical Research, 105(B4), https://doi.org/10.1029/1999JB900400

Chambat, F., \& Valette, B. (2005). Earth gravity up to second order in topography and density. Physics of the Earth and Planetary Interiors, 151(1-2), 89-106. https://doi.org/10.1016/j.pepi.2005.01.002

Cisternas, M., Garrett, E., Wesson, R., Dura, T., \& Ely, L.L. (2017). Unusual geologic evidence of coeval seismic shaking and tsunamis shows variability in earthquake size and recurrence in the area of the giant 1960 Chile earthquake. Marine Geology, 385, 101-113. https://doi.org/10.1016/j.margeo.2016.12.007

Claessens, S. J., \& Hirt, C. (2013). Ellipsoidal topographic potential-New solutions for spectral forward gravity modelling of topography

with respect to a reference ellipsoid. Journal of Geophysical Research. Solid Earth, 118, 5991-6002. https://doi.org/10.1002/2013JB010457

Clift, P. D., Pecher, I., Kukowski, N., \& Hampel, A. (2003). Tectonic erosion of the Peruvian forearc, Lima Basin, by subduction and Nazca Ridge collision. Tectonics, 22(3). https://doi.org/10.1029/2002TC001386

Cobbold, P. R., Rossello, E. A., Roperch, P., Arriagada, C., Gómez, L. A., \& Lima, C. (2007). Distribution, Timing, and Causes of Andean Deformation across South America. Geological Society of London Special Publications, 272, 321-343. https://doi.org/10.1144/GSL.SP.2007.272.01.17 
Contreras-Reyes, E., \& Carrizo, D. (2011). Control of high oceanic features and subduction channel on earthquake ruptures along the Chile-Peru subduction zone. Physics of the Earth and Planetary Interiors, 186 , 49-58. https://doi.org/10.1016/j.pepi.2011.03.002

Contreras-Reyes, E., \& Osses, A. (2010). Lithospheric flexure modeling seaward of the Chile trench: implications for oceanic plate weakening in the Trench Outer Rise region. Geophysical Journal International, 182 (1), 97-112, http://doi.org/10.1111/j.1365-

246X.2010.04629.x

Das, R., Gonzalez, G., de la Llera, J. C., Saez, E., Salazar, P., Gonzalez, J., \& Meneses, C. (2020). A probabilistic seismic hazard assessment of southern Peru and Northern Chile. Engineering Geology, 271 , 105585 . https://doi.org/10.1016/j.enggeo.2020.105585

Drinkwater, M.R., Floberghagen, R., Haagmans, R., Muzi, D., \& Popescu, A. (2003). GOCE: ESA's First Earth Explorer Core Mission. In: Beutler, G., Drinkwater, M.R., Rummel, R., Von Steiger, R. (eds) Earth Gravity Field from Space - From Sensors to Earth Sciences. Space Sciences Series of ISSI, 17. Springer, Dordrecht. https://doi.org/10.1007/97894-017-1333-7_36

Espurt, N., Funiciello, F., Martinod, J., Buillaume, B., Regard, V., Faccenna, C., Brusset, S. (2008). Flat subduction dynamics and deformation of the South American plate: insights from analog modeling. Tectonics, 27, TC3011. https://doi.org/10.1029/2007TC002175

Faccenna, C., Oncken, O., Holt, A. F., \& Becker, T. W. (2017). Initiation of the Andean orogeny by lower mantle subduction. Earth and Planetary Science Letters, 463, 189-201. https://doi.org/10.1016/j.epsl.2017.01.041

García, H. P. A., Gianni, G. M., Lupari, M. N., Sánchez, M. A., Soler, S. R., Ruiz, F., \& Klinger, F. G. L. (2018). Effective elastic thickness in the Central Andes. Correlation to orogenic deformation styles and lower crust high-gravity anomaly. Journal of South American Earth Sciences, 87, 232-246. https://doi.org/10.1016/j.jsames.2017.11.021

Gauger, S., Kuhn, G., Gohl, K., Feigl, T., Lemenkova, P., \& Hillenbrand, C. (2007). Swath-bathymetric mapping. Reports on Polar and Marine Research, 557, 38-45. https://doi.org/10.6084/m9.figshare.7439231

Geersen, J., Behrmann, J. H., Voelker, D., Krastel, S., Ranero, C. R., Diaz-Naveas, J., \& Weinrebe, W. (2011). Active tectonics of the South Chilean marine fore arc (35。 S-40。 S). Tectonics, 30(3), TC3006. https://doi.org/10.1029/2010TC002777

Giorgi, G., Schmidt, T.D., Trainotti, C., Mata-Calvo, R., Fuchs, C., Hoque, M.M., Berdermann, J., Furthner, J., Günther, C., Schuldt, T., Sanjuan, J., Gohlke, M.,
Oswald, M., Braxmaier, C., Balidakis, K., Dick, G., Flechtner, F., Glaser, S., König, R., Michalak, G., Murböck, M., Semmling, M., \& Schuh, H. (2019). Advanced technologies for satellite navigation and geodesy. Advances in Space Research, 64(6), 1256-1273.

https://doi.org/10.1016/j.asr.2019.06.010

Godah, W., Krynski, J., \& Szelachowska, M. (2018). The use of absolute gravity data for the validation of Global Geopotential Models and for improving quasigeoid heights determined from satellite-only Global Geopotential Models. Journal of Applied Geophysics, 152, 38-47. https://doi.org/10.1016/j.jappgeo.2018.03.002

Gvirtzman, Z., Faccenna, C., \& Becker, T. W. (2016). Isostasy, flexure, and dynamic topography. Tectonophysics, 683, 255-271. https://doi.org/10.1016/j.tecto.2016.05.041

Hirt, C., Reußner, E., Rexer, M., \& Kuhn, M. (2016). Topographic gravity modeling for global Bouguer maps to degree 2160: Validation of spectral and spatial domain forward modeling techniques at the 10 microGal level level. Journal of Geophysical Research. Solid Earth, 121, 6846-6862. https://doi.org/10.1002/2016JB013249

Hu, J., Liu, L., Hermosillo, A., \& Zhou, Q. (2016). Simulation of late Cenozoic South American flat-slab subduction using geodynamic models with data assimilation. Earth and Planetary Science Letters, 438, 1-13. https://doi.org/10.1016/j.epsl.2016.01.011

Jamieson, A. J., Fujii, T., Mayor, D. J., Solan, M., Priede, I. G. (2010). Hadal trenches: the ecology of the deepest places on Earth. Trends in Ecology \& Evolution, 25 (3), 190-197. https://doi.org/10.1016/j.tree.2009.09.009

Jamieson, A. J. (2018). A contemporary perspective on hadal science Deep-Sea Research II Topical Studies in Oceanography, 155, 4-10. https://doi.org/10.1016/j.dsr2.2018.01.005

Jamieson, A. J., Stewart, H. A., \& Nargeolet, P.-H. (2020). Exploration of the Puerto Rico Trench in the mid-twentieth century: Today's significance and relevance. Endeavour, 44(1-2), 100719. https://doi.org/10.1016/j.endeavour.2020.100719

Jamieson, A. J., \& Stewart, H. A. (2020). Hadal zones of the Northwest Pacific Ocean. Progress in Oceanography, 102477 (In Press, Corrected Proof).

https://doi.org/10.1016/j.pocean.2020.102477

Klaučo, M., Gregorová, B., Stankov, U., Marković, V., \& Lemenkova, P. (2013a). Determination of ecological significance based on geostatistical assessment: a case study from the Slovak Natura 2000 protected area. Central European Journal of Geosciences, 5(1), 28-42. https://doi.org/10.2478/s13533-012-0120-0 
Klaučo, M., Gregorová, B., Stankov, U., Marković, V., \& Lemenkova, P. (2013b). Interpretation of Landscape Values, Typology and Quality Using Methods of Spatial Metrics for Ecological Planning. Environmental \& Climate Technologies, Oct. 14, 2013. Riga, Latvia. https://doi.org/10.13140/RG.2.2.23026.96963

Klaučo, M., Gregorová, B., Stankov, U., Marković, V., \& Lemenkova, P. (2014). Landscape metrics as indicator for ecological significance: assessment of Sitno Natura 2000 sites, Slovakia. Ecology and Environmental Protection. Minsk, Belarus, 85-90. https://doi.org/10.6084/m9.figshare.7434200

Klaučo, M., Gregorová, B., Stankov, U., Marković, V., \& Lemenkova, P. (2017). Land planning as a support for sustainable development based on tourism: A case study of Slovak Rural Region. Environmental Engineering and Management Journal, 2(16), 449-458.

https://doi.org/10.30638/eemj.2017.045

Knudsen, P., Bingham, R., Andersen, O., \& Rio, M. H. (2011). A global mean dynamic topography and ocean circulation estimation using a preliminary GOCE gravity model. Journal of Geodesy, 85(11), 861-879. https://doi.org/10.1007/s00190-0110485-8

Kuhn, G., Hass, C., Kober, M., Petitat, M., Feigl, T., Hillenbrand, C. D., Kruger, S., Forwick, M., Gauger, S., \& Lemenkova, P. (2006). The response of quaternary climatic cycles in the South-East Pacific: development of the opal belt and dynamics behavior of the West Antarctic ice sheet. Expeditionsprogramm Nr. $75 \quad$ ANT $\quad$ XXIII/4. https://doi.org/10.13140/RG.2.2.11468.87687

Kurowicka, D., \& Cooke, R. M. (2006). Uncertainty Analysis with High Dimensional Dependence Modelling. 302 pp. John Wiley \& Sons, ISBN 978-0470-86306-0

Lara, L. E., Naranjo, J. A., \& Moreno, H. (2004). Rhyodacitic fissure eruption in Southern Andes (Cordón Caulle; 40.5²) after the 1960 (Mw:9.5) Chilean earthquake: a structural interpretation. Journal of Volcanology and Geothermal Research, 138(1-2), 127-138. https://doi.org/10.1016/j.jvolgeores.2004.06.009

Lemenkova, P. (2020a). The geomorphology of the Makran Trench in the context of the geological and geophysical settings of the Arabian Sea. Geology, Geophysics and Environment, 46(3), 205-222. https://doi.org/10.7494/geol.2020.46.3.205

Lemenkova, P. (2020b). GMT-based geological mapping and assessment of the bathymetric variations of the Kuril-Kamchatka Trench, Pacific Ocean. Natural and Engineering Sciences, 5(1), 1-17. https://doi.org/10.28978/nesciences.691708

Lemenkova, P. (2020c). Visualization of the geophysical settings in the Philippine Sea margins by means of GMT and ISC data. Central European
Journal of Geography and Sustainable Development, 2(1), 5-15. https://doi.org/10.6084/m9.figshare.12044799

Lemenkova, P. (2020d). Fractal surfaces of synthetical DEM generated by GRASS GIS module r.surf.fractal from ETOPO1 raster grid. Journal of Geodesy and Geoinformation, 7(1), 86-102. https://doi.org/10.9733/JGG.2020R0006.E

Lemenkova, P. (2020e). GEBCO Gridded Bathymetric Datasets for Mapping Japan Trench Geomorphology by Means of GMT Scripting Toolset. Geodesy and Cartography, 46 (3), 98-112. https://doi.org/10.3846/gac.2020.11524

Lemenkova, P. (2020f). NOAA Marine Geophysical Data and a GEBCO Grid for the Topographical Analysis of Japanese Archipelago by Means of GRASS GIS and GDAL Library. Geomatics and Environmental Engineering, 14(4), 25-45. https://doi.org/10.7494/geom.2020.14.4.25

Lemenkova, P. (2019a). Statistical Analysis of the Mariana Trench Geomorphology Using R Programming Language. Geodesy and Cartography, 45(2), 57-84. https://doi.org/10.3846/gac.2019.3785

Lemenkova, P. (2019b). Topographic surface modelling using raster grid datasets by GMT: example of the Kuril-Kamchatka Trench, Pacific Ocean. Reports on Geodesy and Geoinformatics, 108, 9-22. https://doi.org/10.2478/rgg-2019-0008

Lemenkova, P. (2019c). GMT Based Comparative Analysis and Geomorphological Mapping of the Kermadec and Tonga Trenches, Southwest Pacific Ocean. Geographia Technica, 14(2), 39-48. https://doi.org/10.21163/GT_2019.142.04

Lemenkova, P. (2019d). Geomorphological modelling and mapping of the Peru-Chile Trench by GMT. Polish Cartographical Review, 51(4), 181-194. https://doi.org/10.2478/pcr-2019-0015

Lemenkova, P. (2019e). AWK and GNU Octave Programming Languages Integrated with Generic Mapping Tools for Geomorphological Analysis. GeoScience Engineering, 65 (4), 1-22. https://doi.org/10.35180/gse-2019-0020

Lemenkova, P. (2019f). Geophysical Modelling of the Middle America Trench using GMT. Annals of Valahia University of Targoviste. Geographical Series, 19(2), 73-94. https://doi.org/10.6084/m9.figshare.12005148

Lemenkova, P. (2019g). SAGA GIS for information extraction on presence and conditions of vegetation of northern coast of Iceland based on the Landsat TM. Acta Biologica Marisiensis, 3(2), 10-21. https://doi.org/10.2478/abmj-2020-0007

Lemenkova, P. (2019h). Processing oceanographic data by Python libraries NumPy, SciPy and Pandas. Aquatic Research, 2, 73-91. https://doi.org/10.3153/AR19009

Lemenkova, P. (2019i). Testing Linear Regressions by StatsModel Library of Python for Oceanological 
Data Interpretation. Aquatic Sciences and Engineering, 34, 51-60. https://doi.org/10.26650/ASE2019547010

Lemenkova, P. (2018a). R scripting libraries for comparative analysis of the correlation methods to identify factors affecting Mariana Trench formation. Journal of Marine Technology and Environment, 2, 35-42. https://doi.org/10.6084/m9.figshare.7434167

Lemenkova, P. (2018b). Factor Analysis by R Programming to Assess Variability Among Environmental Determinants of the Mariana Trench. Turkish Journal of Maritime and Marine Sciences, 4, 146-155.

https://doi.org/10.6084/m9.figshare.7358207

Lemenkova, P., Promper, C. \& Glade, T. (2012). Economic Assessment of Landslide Risk for the Waidhofen a.d. Ybbs Region, Alpine Foreland, Lower Austria. In: Eberhardt, E., Froese, C., Turner, A. K. \& Leroueil, S. (Eds.). 11th International Symposium on Landslides \& the 2nd North American Symposium on Landslides \& Engineered Slopes. Protecting Society through Improved Understanding. NASL, June 2-8, 2012. Banff, $A B$, Canada, https://doi.org/10.6084/m9.figshare.7434230

Lemoine, F. G., Kenyon, S. C., Factor, J. K., Trimmer, R.G., Pavlis, N. K., Chinn, D. S., Cox, C. M., Klosko, S. M., Luthcke, S. B., Torrence, M. H., Wang, Y. M., Williamson, R. G., Pavlis, E. C., Rapp R. H., \& Olson, T. R. (1998). The Development of the Joint NASA GSFC and the National Imagery and Mapping Agency (NIMA) Geopotential Model EGM96. NASA/TP-1998-206861, July 1998.

Lim, H., Kim, Y., Clayton, R.W., \& Thurber, C.H. (2018). Seismicity and structure of Nazca Plate subduction zone in southern Peru. Earth and Planetary Science Letters, 498, 334-347. https://doi.org/10.1016/j.epsl.2018.07.014

Lindh, P. (2003). MCV and shear strength of compacted fine-grained tills. 12th Asian Regional Conference on Soil Mechanics and Geotechnical Engineering, 4-8 August 2003. Singapore, 493-496.

Lindh, P., \& Winter, M. G. (2003). Sample Preparation Effects on the Compaction Properties of Swedish Fine-Grained Tills. Quarterly Journal of Engineering Geology \& Hydrogeology, 10(4), 321-330. https://doi.org/10.1144/1470-9236/03-018

Mitasova, H., Overton, M., \& Harmon, R. (2005). Geospatial analysis of a coastal sand dune field evolution: Jockey's Ridge, North Carolina. Geomorphology, 72, 204-221. https://doi.org/10.1016/j.geomorph.2005.06.001

Mitchell, N. C. (2012). Aspects of marine geosciences: a review and thoughts on potential for observing active processes and progress through collabora- tion between ocean sciences. Philosophical Transactions of the Royal Society A, 370, 5567-5612. https://doi.org/10.1098/rsta.2012.0395

Mergili, M., Frank, B., Fischer, J. T., Huggel, C., \& Pudasaini, S. P. (2018). Computational experiments on the 1962 and 1970 landslide events at Huascarán (Peru) with r.avaflow: Lessons learned for predictive mass flow simulations. Geomorphology, 322, 15-28. https://doi.org/10.1016/j.geomorph.2018.08.032

Meurers, B. (2017). Chapter 2 - The Physical Meaning of Bouguer Anomalies-General Aspects Revisited. In: Understanding the Bouguer Anomaly A Gravimetry Puzzle, 13-30. https://doi.org/10.1016/B978-0-12-8129135.00001-4

Neteler, M. (2001). Towards a stable Open Source GIS: Status and Future Directions in GRASS Development. In: The Geomatics Workbook (ed. Brovelli, M.). Polytec. di Milano, Italy, 2nd ed. http://geomatica.ing.unico.it/workbooks2/

Neteler, M., \& Mitasova, H. (2004). Open Source GIS: A GRASS GIS Approach, 2nd Ed. Kluwer International Series in Engineering and Computer Science 773, Springer/Kluwer Academic Press, NY/Boston. Neteler, M., \& Mitasova, H. (2008). Open Source GIS. A GRASS GIS Approach. 3rd Ed. New York, Springer. 417 pp. ISBN-13: 978-0-387-35767-6

Neteler, M. (2005). Time series processing of MODIS satellite data for landscape epidemiological applications. International Journal of Geoinformatics, 1(1): 133-138.

Olson, C. J., Becker, J. J., \& Sandwell, D. T. (2016). SRTM15_PLUS: Data fusion of Shuttle Radar Topography Mission (SRTM) land topography with measured and estimated seafloor topography (NCEI Accession 0150537). NOAA National Centers for Environmental Information. Dataset. https://accession.nodc.noaa.gov/0150537 Accessed [02.05.2020].

Pavlis, N. K., Holmes, S. A., Kenyon, S. C., \& Factor, J. K. (2012). The development and evaluation of the Earth Gravitational Model 2008 (EGM2008). Journal of Geophysical Research: Solid Earth, 117 (B4). https://doi.org/10.1029/2011JB008916

Pivetta, T., \& Braitenberg, C. (2020). Sensitivity of gravity and topography regressions to earth and planetary structures. Tectonophysics, 774, 228299.

https://doi.org/10.1016/j.tecto.2019.228299

Pyrcz, M. J., \& Deutsch, C. V. (2014). Geostatistical Reservoir Modeling. 2nd Ed., New York, Oxford University Press, pp. 448. ISBN-13: 9780199731442

Reynard, B., Nakajima, J., \& Kawakatsu, H. (2010). Earthquakes and plastic deformation of anhydrous 
slab mantle in double Wadati-Benioff zones. Geophysical Research Letters, 37 (24). https://doi.org/10.1029/2010GL045494

Ruthven, R. Singleton, J., Seymour, N., Gomila, R., Arancibia, G., Stockli, D.F., Ridley, J., \& Magloughlin, J. (2020). The geometry, kinematics, and timing of deformation along the southern segment of the Paposo fault zone, Atacama fault system, northern Chile. Journal of South American Earth Sciences, $\quad 97, \quad 102355$. https://doi.org/10.1016/j.jsames.2019.102355

Sandwell, D. T., \& Smith, W. H. F. (2009). Global marine gravity from retracked Geosat and ERS-1 altimetry: ridge segmentation versus spreading rate. Journal of Geophysical Research, 114, B01411. https://doi.org/10.1029/2008JB006008

Schenke, H. W., \& Lemenkova, P. (2008). Zur Frage der Meeresboden-Kartographie: Die Nutzung von AutoTrace Digitizer für die Vektorisierung der Bathymetrischen Daten in der Petschora-See. Hydrographische Nachrichten, 81, 16-21. https://doi.org/10.6084/m9.figshare.7435538

Scherwath, M., Contreras-Reyes, E., Flueh, E.R., Grevemeyer, I., Krabbenhoeft, A., Papenberg, C., Petersen, C. J., \& Weinrebe, R. W. (2009). Deep lithospheric structures along the southern central Chile margin from wide-angle P-wave modelling. Geophysical Journal International, 179(1), 579600. https://doi.org/10.1111/j.1365246X.2009.04298.x

Seibold, E., \& Berger, W. H. (1993). The Sea Floor. An Introduction to Marine Geology. Springer-Verlag Berlin Heidelberg. https://doi.org/10.1007/978-3662-22519-6

Sofia, G., Pirotti, F., \& Tarolli, P. (2013). Variations in multiscale curvature distribution and signatures of LiDAR DTM errors. Earth Surface Processes and Landforms, 38, 1116-1134. https://doi.org/10.1002/esp.3363

Steinberger, B., Werner, S. C., \& Torsvik, T. H. (2010). Deep versus shallow origin of gravity anomalies, topography and volcanism on Earth, Venus and Mars. Icarus, 207, 564-577. https://doi.org/10.1016/j.icarus.2009.12.025.

Stevenson, J. A., Sun, X., \& Mitchell, N. C. (2010). Despeckling SRTM and other topographic data with a denoising algorithm. Geomorphology, 114, 238-252. morph.2009.07.006

Stewart, H. A., Jamieson, A. J. (2018). Habitat heterogeneity of hadal trenches: Considerations and implications for future studies. Progress in Oceanography, 161, 47-65. https://doi.org/10.1016/j.pocean.2018.01.007

Stewart, H. A., \& Jamieson, A. J. (2019). The five deeps: The location and depth of the deepest place in each of the world's oceans. Earth-Science Reviews, 197, 102896. https://doi.org/10.1016/j.earscirev.2019.102896

Suetova, I. A., Ushakova, L. A., \& Lemenkova, P. (2005). Geoinformation mapping of the Barents and Pechora Seas. Geography and Natural Resources, 4, 138-142. https://doi.org/10.6084/m9.figshare.7435535

Tamay, J., Galindo-Zaldívar, J., Martos, Y. M., \& Soto, J. (2018). Gravity and magnetic anomalies of ecuadorian margin: Implications in the deep structure of the subduction of Nazca Plate and Andes Cordillera. Journal of South American Earth Sciences, 85, 68-80. https://doi.org/10.1016/j.jsames.2018.04.020

Tenzer, R., Chen, W., \& Ye, Z. (2015). Empirical model of the gravitational field generated by the oceanic lithosphere. Advances in Space Research, 55(1), 72-82. https://doi.org/10.1016/j.asr.2014.09.023

Vanicek P., Janák J., \& Huang J. (2001) Mean Vertical Gradient of Gravity. In: Sideris M.G. (eds) Gravity, Geoid and Geodynamics 2000. International Association of Geodesy Symposia, 123. Springer, Berlin, Heidelberg. https://doi.org/10.1007/978-3662-04827-6_43

Vaniček, P., Novák, P., \& Martinec, Z. (2001). Geoid, topography, and the Bouguer plate or shell. Journal of Geodesy, 75(4), 210-215. https://doi.org/10.1007/s001900100165

Webster, R., \& Oliver, M. A. (2007). Geostatistics for Environmental Scientists. John Wiley \& Sons, 330 pp. ISBN: 978-0-470-02858-2

Yan, H., Ballmer, M. D., \& Tackley, P. J. (2020). The evolution and distribution of recycled oceanic crust in the Earth's mantle: Insight from geodynamic models. Earth and Planetary Science Letters, 537, 116171. https://doi.org/10.1016/j.epsl.2020.116171

Yáñez, G., Cembrano, J., Pardo, M., Ranero, C., \& Selles, D. (2002). The Challenger-Juan FernándezMaipo major tectonic transition of the Nazca-Andean subduction system at $33-34^{\circ} \mathrm{S}$ : geodynamic evidence and implications. Journal of South American Earth Sciences, 15, 23-38. https://doi.org/10.1016/S0895-9811(02)00004-4 